\title{
Early-Life Metabolic and Hormonal Markers in Blood and Growth until Age 2 Years: Results from a Randomized Controlled Trial in Healthy Infants Fed a Modified Low-Protein Infant Formula
}

\author{
Stefanie M. P. Kouwenhoven ${ }^{1}$, Manja Fleddermann ${ }^{2}$, Martijn J. J. Finken ${ }^{3}{ }^{\mathbb{D}}$, Jos W. R. Twisk ${ }^{4}$, \\ Eline M. van der Beek ${ }^{5}$, Marieke Abrahamse-Berkeveld ${ }^{6}$, Bert J. M. van de Heijning ${ }^{6}$, \\ Dewi van Harskamp ${ }^{7}$ (D), Johannes B. van Goudoever ${ }^{1, *,+}$ and Berthold V. Koletzko ${ }^{2,+}$
}

\section{check for} updates

Citation: Kouwenhoven, S.M.P.; Fleddermann, M.; Finken, M.J.J.; Twisk, J.W.R.; van der Beek, E.M.; Abrahamse-Berkeveld, M.; van de Heijning, B.J.M.; van Harskamp, D. van Goudoever, J.B.; Koletzko, B.V. Early-Life Metabolic and Hormonal Markers in Blood and Growth until Age 2 Years: Results from a Randomized Controlled Trial in Healthy Infants Fed a Modified Low-Protein Infant Formula. Nutrients 2021, 13, 1159. https:// doi.org/10.3390/nu13041159

Academic Editor: Maria Lorella Gianni

Received: 29 January 2021 Accepted: 29 March 2021 Published: 1 April 2021

Publisher's Note: MDPI stays neutral with regard to jurisdictional claims in published maps and institutional affiliations.

Copyright: (c) 2021 by the authors. Licensee MDPI, Basel, Switzerland. This article is an open access article distributed under the terms and conditions of the Creative Commons Attribution (CC BY) license (https:// creativecommons.org/licenses/by/ $4.0 /)$.
1 Emma Children's Hospital, Vrije Universiteit, University of Amsterdam, Amsterdam UMC, 1081 Amsterdam, The Netherlands; s.kouwenhoven@amsterdamumc.nl

2 Department of Peadiatrics, Dr. von Hauner Children's Hospital, LMU University Hospitals, LMU_Ludwig-Maximilians-Universität Munich, 80377 Munich, Germany; manja-fleddermann@web.de (M.F.); berthold.koletzko@med.uni-muenchen.de (B.V.K.)

3 Department of Paediatric Endocrinology, Emma Children's Hospital, Vrije Universiteit, Amsterdam UMC, 1081 Amsterdam, The Netherlands; m.finken@amsterdamumc.nl

4 Epidemiology and Data Science, Amsterdam UMC, 1081 Amsterdam, The Netherlands; jwr.twisk@amsterdamumc.nl

5 Department of Pediatrics, University Medical Center Groningen, University of Groningen, 9713 Groningen, The Netherlands; e.m.van.der.beek@umcg.nl

6 Danone Nutricia Research, 3584 Utrecht, The Netherlands; marieke.abrahamse@danone.com (M.A.-B.); bert.vandeheijning@danone.com (B.J.M.v.d.H.)

7 Stable Isotope Laboratory, University of Amsterdam, Amsterdam UMC, 1105 Amsterdam, The Netherlands d.vanharskamp@amsterdamumc.nl

* Correspondence: h.vangoudoever@amsterdamumc.nl; Tel.: +31-020-5663340

$\dagger$ These authors contributed equally to this work.

Abstract: Background: High protein intake in early life is associated with an increased risk of childhood obesity. Dietary protein intake may be a key mechanistic modulator through alterations in endocrine and metabolic responses. Objective: We aimed to determine the impact of different protein intake of infants on blood metabolic and hormonal markers at the age of four months. We further aimed to investigate the association between these markers and anthropometric parameters and body composition until the age of two years. Design: Term infants received a modified lowprotein formula (mLP) $(1.7 \mathrm{~g}$ protein $/ 100 \mathrm{kcal})$ or a specifically designed control formula (CTRL) $(2.1 \mathrm{~g}$ protein $/ 100 \mathrm{kcal})$ until 6 months of age in a double blinded RCT. The outcomes were compared with a breast-fed (BF) group. Glucose, insulin, leptin, IGF-1, IGF-BP1, -BP2, and -BP3 levels were measured at the age of 4 months. Anthropometric parameters and body composition were assessed until the age of 2 years. Groups were compared using linear regression analysis. Results: No significant differences were observed in any of the blood parameters between the formula groups ( $n=53 \mathrm{mLP} ; n=44 \mathrm{CTRL}$ ) despite a significant difference in protein intake. Insulin and HOMA-IR were higher in both formula groups compared to the BF group $(n=36)(p<0.001)$. IGF-BP1 was lower in both formula groups compared to the BF group $(p<0.01)$. We found a lower IGF-BP2 level in the CTRL group compared to the BF group $(p<0.01)$ and a higher IGF-BP3 level in the mLP group compared to the BF group $(p=0.03)$. There were no significant differences in glucose, leptin, and IGF-1 between the three feeding groups. We found specific associations of all early-life metabolic and hormonal blood parameters with long-term growth and body composition except for IGF-1. Conclusions: Reducing protein intake by $20 \%$ did not result in a different metabolic profile in formula-fed infants at 4 months of age. Formula-fed infants had a lower insulin sensitivity compared to breast-fed infants. We found associations between all metabolic and hormonal markers (except for IGF-1) determined at age 4 months and growth and body composition up to two years of age. 
Keywords: early childhood; infant nutrition; growth; body composition; childhood obesity; protein intake

\section{Introduction}

There is evidence to suggest that protein intake during the first months of life has long-lasting effects on growth, body composition, and obesity risk [1-5]. The mechanisms through which an increased protein intake may affect growth and body composition remain to be clarified. The anabolic hormones insulin and insulin-like growth factor-1 (IGF-1) are responsive to fluctuations in protein intake [6] and have growth-stimulating properties $[7,8]$.

Formula-fed infants have been shown to have higher concentrations of insulin [9-11] and IGF-1 [11-14] compared to breast-fed infants. This has often been attributed to the higher protein contents of formula feeding. Indeed, a randomized controlled trial investigating the effect of formula feeding with different protein content found that concentrations of IGF-1 and C-peptide excretion (which is an indicator of insulin secretion) were higher among infants receiving formula with a higher protein content [11].

The bioactivity of IGF-1 is regulated by six IGF-binding proteins (IGF-BP1-6). Circulating IGF-1 is primarily bound to IGF-BP3 in addition to an acid-labile subunit, thus offering protection from early degradation in the circulation [15]. In target tissues, liberated IGF-1 can bind to the IGF-1 receptor [16]. Some IGF-BPs possess intrinsic biological activities through IGF-independent mechanisms [17,18]. Accumulating evidence suggests that IGF-BP1 and IGF-BP2 may increase insulin sensitivity directly [18] and cluster with components of the metabolic syndrome in obese children [19] Hence, these IGF-BPs may serve as a useful biomarker of insulin sensitivity in early childhood [20].

The appetite-regulating hormone leptin may also explain the link between protein intake and infant growth and body composition. Leptin is involved in regulating satiety and energy balance [21]. Circulating leptin levels have been shown to correlate well with the total fat mass [22]. Protein intake may influence the amount of adipose tissue and, therefore, can circulate leptin.

We found that feeding an infant formula with a modified amino acid profile and a lower protein content (mLP formula) is safe and supports adequate growth despite a lower urea concentration similar to infants receiving an infant formula with a standard amount of protein (CTRL formula) [23]. Furthermore, no differences in growth parameters or body composition were observed between the mLP group and the CTRL group at the ages of 4 and 6 months. Since the infants in the mLP group had a lower total protein intake, we hypothesized that infants fed a mLP formula have a different metabolic profile than infants fed CTRL formula more closely resembling that of breast-fed infants. We further investigated the associations between metabolic/hormonal markers and anthropometric parameters, including body composition.

\section{Materials and Methods}

This study was part of a double-blind randomized controlled trial (ProtEUs study) conducted in two centers: Amsterdam UMC (location VU University Medical Center, Amsterdam, the Netherlands) and Dr. von Hauner Children's Hospital (LMU—LudwigMaximilians-Universität, Munich, Germany). Healthy, term-born, formula-fed ( $n=178)$, and breast-fed $(n=67)$ infants were enrolled between 22 October 2014 and 29 December 2016. Formula-fed infants eligible for participation were randomized to receive either the $\mathrm{mLP}$ with a protein content of $1.7 \mathrm{~g} / 100 \mathrm{kcal}$ or CTRL formula with a protein content of $2.1 \mathrm{~g} / 100 \mathrm{kcal}$ from baseline (an average age of one month) up to the age of 6 months. All infants were fed ad libitum throughout the study period. The study formulas were isoenergetic $(67 \mathrm{kcal} / 100 \mathrm{~mL})$ and had identical nutritional composition except for protein and lactose; the latter was used to make the formula isoenergetic. Volume intake in 
both formula groups was similar across all ages, and no compensatory volume intake was observed in the mLP group [23]. This confirms that the targeted difference of $20 \%$ in protein intake was established between the MLP and CTRL groups during the intervention period.

The outcomes were compared with a breast-fed (BF) group. The breast-fed group consisted of infants of parents who intended to (fully) breast-feed for 6 months. Parents were allowed to introduce complementary feeding no earlier than after the age of 17 weeks in line with national guidelines. The trial was approved by the Institutional Review Boards of the VU University Medical Center Amsterdam and the Medical Faculty, LMU Munich. The study was conducted according to International Conference on Harmonisation-Good Clinical Practice (ICH-GCP) principles and in compliance with the principles of the Declaration of Helsinki. An independent data safety monitoring board assessed for trial safety. Written informed consent was obtained from all participants' parents or guardians. Further details of the study are described elsewhere [23].

\subsection{Procedures}

The intervention period started at an average age of one month and lasted until the age of 6 months. Infants visited the hospital 3 times during the intervention period: at an average age of 1 month (baseline), at 4 months of age, and at 6 months of age. The follow-up period included study visits at 1 and 2 years of age. During these visits, anthropometry and body composition measurements were performed by trained study personnel according to standard protocols. At the age of 4 months, a venous blood sample from a hand vein was obtained after at least $3 \mathrm{~h}$ of fasting. Parents were allowed to introduce complementary feeding no earlier than after the age of 4 months in line with national guidelines.

\subsection{Anthropometrics}

Weight was measured (without clothing or diaper) to 0.5-g accuracy on a balance scale (MARSDEN, Rotherham, UK). At the age of 1 year, length was measured with a flexible measuring board (SECA, Birmingham, UK) to the nearest $0.1 \mathrm{~cm}$. At 2 years, height was measured with a digital stadiometer (SECA, Birmingham, UK) to the nearest $0.1 \mathrm{~cm}$. The average of two measurements was used in the analysis.

\subsection{Body Composition}

Air-displacement plethysmography (ADP) technique is conducted as follows: At the age of 1, 4, and 6 months, we used the Pea Pod (Cosmed, Concord, MA, USA) and at the age of 2 years we used the Bod Pod (Pediatric Option Body Composition System; Cosmed, Concord, MA, USA) to measure body composition.

\subsection{Deuterium Oxide Dilution $\left(\mathrm{D}_{2} \mathrm{O}\right)$ Technique}

At the age of 1 year, body composition was estimated using the deuterium dilution technique [24,25]. After the collection of a baseline saliva sample ( $\mathrm{t} 0)$, a small amount of $0.2 \mathrm{~mL}$ or $0.4 \mathrm{~mL} \mathrm{D}_{2} \mathrm{O}$ per kilogram body weight was orally administered. Saliva was collected using a saliva collection kit at 5 distinct time points after the administration of $\mathrm{D}_{2} \mathrm{O}$, (in hours: $\mathrm{t} 6$ or $\mathrm{t} 10, \mathrm{t} 24, \mathrm{t} 48, \mathrm{t} 96$, and $\mathrm{t} 168$ ). All samples were stored frozen at $-20^{\circ} \mathrm{C}$ prior to analysis. The saliva was recovered from the kits by centrifugation $(10 \mathrm{~min}, 4000 \times g$, $20^{\circ} \mathrm{C}$ ). The details of the procedures are described elsewhere [26]. A fat-free mass was calculated from total body water using age- and sex-specific conversion factors for children up to 2 years of age [27].

\subsection{Laboratory Analyses}

Venous blood was collected in a $2.5-\mathrm{mL}$ serum tube and a $0.5-\mathrm{mL}$ heparin tube. This was divided into six different aliquots after centrifugation $\left(10 \mathrm{~min}, 1800 \times \mathrm{g}, 20^{\circ} \mathrm{C}\right)$. Samples were stored at $-80^{\circ} \mathrm{C}$ and thawed only once just before analysis. Glucose levels were assessed on a Beckman Coulter AU5800/AU 680 (enzymatic UV-assay) and insulin concentration on a Roche Cobas 8000/e411 (electrochemiluminescence immunoassay (ECLIA)). 
Levels of IGF-1, IGF-binding proteins, and leptin were estimated using ELISA (Mediagnost Inc., Reutlingen, Germany).

\subsection{Outcomes}

Differences existed between the concentration of glucose, insulin, leptin, IGF-1, IGFBP1, IGF-BP2, and IGF-BP3, and the homeostasis model assessment (HOMA-IR) [28] between $\mathrm{mLP}, \mathrm{CTRL}$, and BF groups at the age of 4 months.

Associations between these metabolic and hormonal markers and anthropometric parameters and body composition until the age of 2 years (non-randomized).

\section{Statistical Analyses}

Insulin, HOMA-IR, and IGF-BP1 were log transformed (natural log-transformation) before statistical analysis. Normally distributed data were presented as mean $\pm \mathrm{SD}$ and skewed data as medians (interquartile ranges-IQRs). The differences in outcome between the groups at the age of four months were analyzed with linear regression analysis and adjustments were made for sex. We compared two feeding groups per analysis (mLP vs. CTRL, mLP vs. BF, CTRL vs. BF).

Associations between metabolic and hormonal markers and anthropometric parameters and body composition were analyzed using a linear mixed model analysis. Linear mixed models were used to consider the dependency of the observations within the child. Interactions were added to obtain the associations at different time points (4 months, 6 months, 1 year, and 2 years). The analyses were adjusted for feeding group and sex. Statistical analyses were performed using the Statistical Package for the Social Sciences (SPSS) version 26, and a significance level of $5 \%$ was used for all comparisons.

\section{Results}

At the age of 4 months, we collected blood samples of 134 infants out of the 238 infants who participated in this trial at that age (Table 1). Of these samples, 53 were fed with mLP formula, 45 with CTRL formula, and 36 were breast-fed. The anthropometrics and body composition of these children are presented in Table 2, and the metabolic and hormonal markers are shown in Table 3. No blood samples were obtained from 104 infants due to unsuccessful draws or parental objection.

Table 1. Infant characteristics.

\begin{tabular}{|c|c|c|c|c|}
\hline & $\operatorname{mLP}(n=53)$ & CTRL $(n=45)$ & $\mathrm{BF}(n=36)$ & Total Group $(n=134)$ \\
\hline \multicolumn{5}{|l|}{ Infant characteristics } \\
\hline Boys $[n(\%)]$ & $23(43.4)$ & $20(44.4)$ & $14(38.9)$ & $57(42.5)$ \\
\hline Caucasian $[n(\%)]$ & $45(84.9)$ & $37(82.2)$ & $31(86.1)$ & $113(84.3)$ \\
\hline Gestational age (Wk) & $39.5 \pm 1.2$ & $39.8 \pm 1.2$ & $39.9 \pm 1.1$ & $39.7 \pm 1.2$ \\
\hline Birth weight $(\mathrm{g})$ & $3418 \pm 366$ & $3402 \pm 437$ & $3400 \pm 284$ & $3408 \pm 370$ \\
\hline Caesarean delivery $[n(\%)]$ & $18(34.0)$ & $14(31.1)$ & $7(19.4)$ & $39(29.1)$ \\
\hline Ever breast-fed $[n(\%)]$ & $27(50.9)$ & $20(44.4)$ & $36(100)$ & $83(61.9)$ \\
\hline Age at baseline (d) & $30 \pm 9$ & $31 \pm 10$ & $31 \pm 8$ & $31 \pm 9$ \\
\hline Age at visit 4 mo (mo) & $3.9 \pm 0.1$ & $3.9 \pm 0.1$ & $3.9 \pm 0.1$ & $3.9 \pm 0.1$ \\
\hline Randomized in Amsterdam & $35(66.0)$ & $25(55.6)$ & $27(75)$ & $87(64.9)$ \\
\hline
\end{tabular}

Data are presented as mean \pm SD or $n(\%)$. BF, breast-fed; CTRL, control formula; mLP, modified low-protein formula. 
Table 2. Anthropometric parameters at 4 months, 6 months, 1 year, and 2 years of age.

\begin{tabular}{|c|c|c|c|c|c|c|}
\hline & \multicolumn{2}{|c|}{$\operatorname{mLP}(n=53)$} & \multicolumn{2}{|c|}{ CTRL $(n=45)$} & \multicolumn{2}{|c|}{ BF $(n=36)$} \\
\hline & $n$ & & $n$ & & $n$ & \\
\hline \multicolumn{7}{|c|}{ Anthropometry } \\
\hline \multicolumn{7}{|l|}{ Weight (g) } \\
\hline 4 months & 53 & $6647 \pm 648$ & 45 & $6621 \pm 644$ & 36 & $6307 \pm 774$ \\
\hline 6 months & 53 & $7695 \pm 804$ & 44 & $7770 \pm 753$ & 36 & $7241 \pm 827$ \\
\hline 1 year & 44 & $9548 \pm 1143$ & 37 & $9621 \pm 1036$ & 29 & $9302 \pm 860$ \\
\hline 2 years & 41 & $12,400 \pm 1598$ & 32 & $12,195 \pm 1200$ & 28 & $12,103 \pm 1040$ \\
\hline \multicolumn{7}{|l|}{ Length $(\mathrm{cm})$} \\
\hline 4 months & 53 & $63.9 \pm 2.0$ & 45 & $63.8 \pm 2.1$ & 36 & $63.4 \pm 2.3$ \\
\hline 6 months & 53 & $68.0 \pm 2.2$ & 44 & $68.3 \pm 2.4$ & 36 & $67.0 \pm 2.5$ \\
\hline 1 year & 44 & $75.7 \pm 2.6$ & 37 & $75.8 \pm 2.4$ & 29 & $74.7 \pm 2.2$ \\
\hline 2 years & 41 & $86.9 \pm 3.4$ & 32 & $86.8 \pm 3.1$ & 28 & $86.1 \pm 2.3$ \\
\hline \multicolumn{7}{|c|}{ Body composition } \\
\hline \multicolumn{7}{|l|}{ Fat mass (g) } \\
\hline 4 months & 52 & $1738 \pm 335$ & 43 & $1712 \pm 414$ & 33 & $1586 \pm 461$ \\
\hline 6 months & 50 & $1985 \pm 430$ & 39 & $2023 \pm 477$ & 36 & $1861 \pm 461$ \\
\hline 1 year & 15 & $1916 \pm 950$ & 12 & $1941 \pm 701$ & 16 & $1805 \pm 822$ \\
\hline 2 years & 24 & $2917 \pm 1285$ & 14 & $2156 \pm 1123$ & 22 & $2427 \pm 874$ \\
\hline \multicolumn{7}{|l|}{ Fat (\%) } \\
\hline 4 months & 52 & $25.7 \pm 3.4$ & 43 & $25.3 \pm 4.7$ & 33 & $24.5 \pm 5.0$ \\
\hline 6 months & 50 & $25.4 \pm 3.6$ & 39 & $25.7 \pm 4.5$ & 36 & $25.2 \pm 4.6$ \\
\hline 1 year & 15 & $19.1 \pm 8.5$ & 12 & $20.1 \pm 6.6$ & 16 & $19.1 \pm 8.0$ \\
\hline 2 years & 24 & $22.2 \pm 7.7$ & 14 & $17.1 \pm 7.7$ & 22 & $19.8 \pm 7.1$ \\
\hline \multicolumn{7}{|c|}{ Fat free mass (g) } \\
\hline 4 months & 52 & $5014 \pm 463$ & 43 & $5018 \pm 471$ & 33 & $4796 \pm 484$ \\
\hline 6 months & 50 & $5789 \pm 549$ & 39 & $5781 \pm 559$ & 36 & $5455 \pm 580$ \\
\hline 1 year & 15 & $7921 \pm 1123$ & 12 & $7621 \pm 787$ & 16 & $7453 \pm 801$ \\
\hline 2 years & 24 & $9858 \pm 605$ & 14 & $10,099 \pm 627$ & 22 & $9858 \pm 1148$ \\
\hline
\end{tabular}

Data are presented as mean $\pm \mathrm{SD}$. BF, breast-fed; CTRL, control formula; mLP, modified low-protein formula.

Table 3. Metabolic and hormonal markers at 4 months of age.

\begin{tabular}{ccccccc}
\hline & \multicolumn{2}{c}{ mLP } & \multicolumn{3}{c}{ CTRL } & BF \\
\cline { 2 - 7 } & $\boldsymbol{n}$ & & $\boldsymbol{n}$ & & $\boldsymbol{n}$ & \\
\hline Glucose (mmol/L) & 53 & $4.95 \pm 0.38$ & 44 & $4.87 \pm 0.34$ & 36 & $4.88 \pm 0.37$ \\
Insulin $(\mu \mathrm{HU} / \mathrm{mL})$ & 52 & $5.35(3.65,8.08)$ & 44 & $5.60(3.45,9.28)$ & 36 & $3.15(1.85,5.28)$ \\
HOMA-IR & 52 & $1.15(0.78,1.85)$ & 44 & $1.23(0.74,1.99)$ & 36 & $0.69(0.38,1.13)$ \\
Leptin $(\mathrm{ng} / \mathrm{mL})$ & 45 & $5.66 \pm 3.19$ & 38 & $6.00 \pm 2.40$ & 31 & $5.60 \pm 5.18$ \\
IGF-1 $(\mathrm{ng} / \mathrm{mL})$ & 48 & $25.41(6.23,88.13)$ & 39 & $27.66(8.78,81.36)$ & 32 & $36.29(5.19,70.18)$ \\
IGF-BP1 $(\mathrm{ng} / \mathrm{mL})$ & 47 & $7.95(4.70,14.42)$ & 39 & $8.37(6.14,11.98)$ & 32 & $15.60(7.90,20.62)$ \\
IGF-BP2 $(\mathrm{ng} / \mathrm{mL})$ & 48 & $523 \pm 230$ & 38 & $471 \pm 154$ & 32 & $594 \pm 179$ \\
IGF-BP3 $(\mathrm{ng} / \mathrm{mL})$ & 48 & $3050 \pm 612$ & 39 & $3002 \pm 521$ & 32 & $2777 \pm 548$ \\
\hline
\end{tabular}

Data are presented as mean \pm SD or median (IQR). BF, breast-fed; CTRL, control formula; mLP, modified low-protein formula.

\subsection{Differences between Feeding Groups}

No significant differences in metabolic and hormonal markers were found between the mLP group and the CTRL group (Table 4, Figures 1 and 2). Nor did we find any significant differences in glucose, IGF-1 concentration (Table 4), or leptin levels between the three feeding groups (Table 4, Figure 1). However, both insulin level and HOMA-IR were significantly higher in formula-fed infants compared to breast-fed infants (Table 4, Figure 2) while IGF-BP1 was significantly lower in both formula groups compared to the 
BF group (Table 4). IGF-BP2 was significantly lower in the CTRL group compared to the BF group but not different between the mLP and the BF group (Table 4).

Table 4. Differences in metabolic and hormonal markers between feeding groups at 4 months of age.

\begin{tabular}{|c|c|c|c|c|c|c|c|c|c|}
\hline & \multicolumn{3}{|c|}{ mLP vs. CTRL (mLP Minus CTRL) } & \multicolumn{3}{|c|}{ mLP vs. BF (mLP Minus BF) } & \multicolumn{3}{|c|}{ CTRL vs. BF (CTRL Minus BF) } \\
\hline & & $95 \% \mathrm{CI}$ & $p$ & & $95 \%$ CI & $p$ & & $95 \% \mathrm{CI}$ & $p$ \\
\hline $\begin{array}{l}\text { Glucose }{ }^{1} \\
\text { (mmol/L) }\end{array}$ & 0.07 & $-0.07,0.22$ & 0.33 & 0.06 & $-0.1,0.21$ & 0.45 & -0.01 & $-0.17,0.15$ & 0.87 \\
\hline $\begin{array}{l}\text { Insulin }{ }^{2} \\
(\mu \mathrm{U} / \mathrm{mL})\end{array}$ & 0.96 & $0.74,1.23$ & 0.72 & 1.69 & $1.30,2.20$ & $<0.001$ & 1.77 & $1.34,2.33$ & $<0.001$ \\
\hline HOMA-IR ${ }^{2}$ & 0.96 & $0.74,1.25$ & 0.79 & 1.70 & $1.29,2.25$ & $<0.001$ & 1.76 & $1.32,2.35$ & $<0.001$ \\
\hline $\begin{array}{l}\text { Leptin }^{1} \\
\text { (ng/mL) }\end{array}$ & -0.44 & $-2.00,1.12$ & 0.58 & 0.05 & $-1.60,1.70$ & 0.95 & 0.49 & $-1.23,2.20$ & 0.57 \\
\hline $\begin{array}{l}\text { IGF-1 } 2,3 \\
(\mathrm{ng} / \mathrm{mL})\end{array}$ & 0.86 & $0.30,2.49$ & 0.86 & 0.92 & $0.30,2.82$ & 0.72 & 0.79 & $0.24,2.56$ & 0.83 \\
\hline $\begin{array}{l}\text { IGF-BP1 }^{2} \\
(\mathrm{ng} / \mathrm{mL})\end{array}$ & 0.92 & $0.67,1.27$ & 0.63 & 0.58 & $0.41,0.81$ & $<0.01$ & 0.62 & $0.44,0.89$ & $<0.01$ \\
\hline $\begin{array}{l}\text { IGF-BP2 }^{1} \\
\text { (ng/mL) }\end{array}$ & 46 & $-37,129$ & 0.27 & -69 & $-156,17$ & 0.12 & -115 & $-207,-24$ & 0.014 \\
\hline $\begin{array}{c}\text { IGF-BP3 }^{1} \\
(\mathrm{ng} / \mathrm{mL})\end{array}$ & 36 & $-204,276$ & 0.77 & 277 & 24,531 & 0.03 & 241 & $-24,507$ & 0.08 \\
\hline
\end{tabular}

Values are differences between feeding groups compared with linear regression analysis adjusted for sex. ${ }^{1}$ differences between the groups; ${ }^{2}$ differences between the groups in ratio; ${ }^{3} p$ value calculated with Mann-Whitey U. BF, breast-fed; CTRL, control formula; mLP, modified low-protein formula.

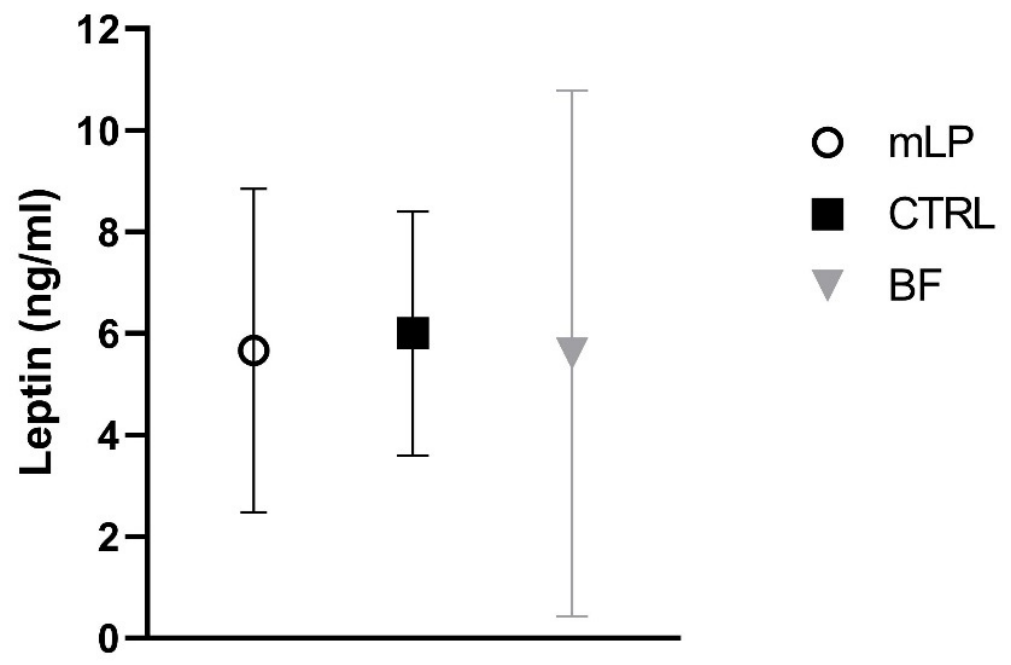

Figure 1. Leptin at 4 months of age. Mean \pm SD. 


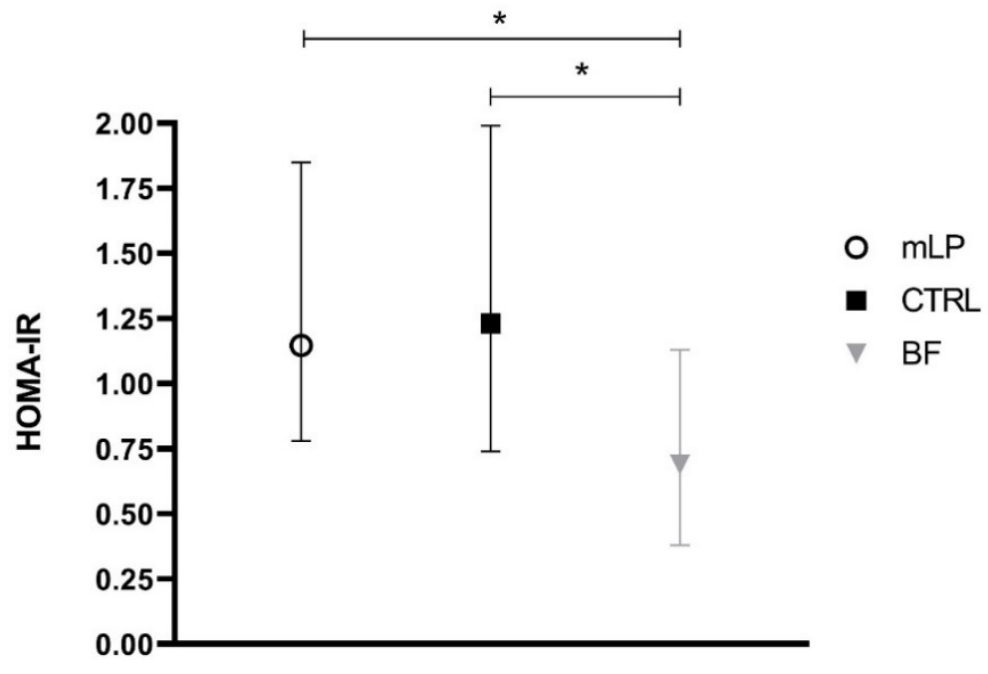

Figure 2. HOMA-IR at 4 months of age. Median (IQR), ${ }^{*} p<0.001$.

In contrast, IGF-BP3 was significantly higher in the mLP group compared to the BF group but not different between the BF group and the CTRL group (Table 4). The ratio IGF-1/IGFBP-3 was not different between the feeding groups (data not shown).

4.2. Associations between Metabolic and Hormonal Markers and Anthropometric Parameters at 4 Months of Age

At the age of 4 months, we found a positive association between leptin and all anthropometric outcomes, including body composition. We further found that IGF-BP1 was negatively associated with length. IGF-BP2 was negatively associated with weight and fat-free mass while IGF-BP3 was positively associated with weight and fat-free mass (Table 5). 
Table 5. Metabolic and hormonal markers at 4 months in relation to anthropometric parameters and body composition through the age of 2 years.

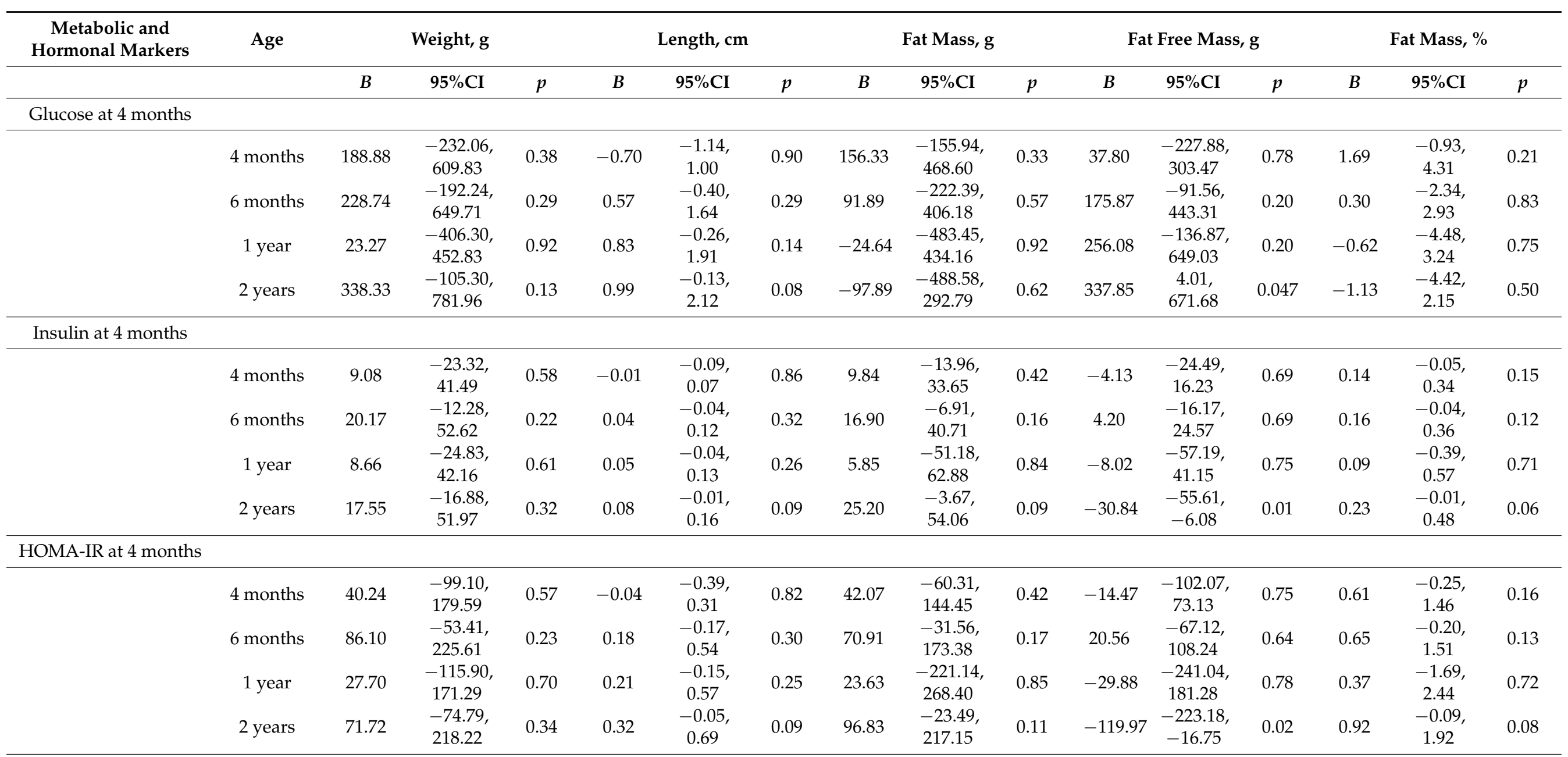


Table 5. Cont.

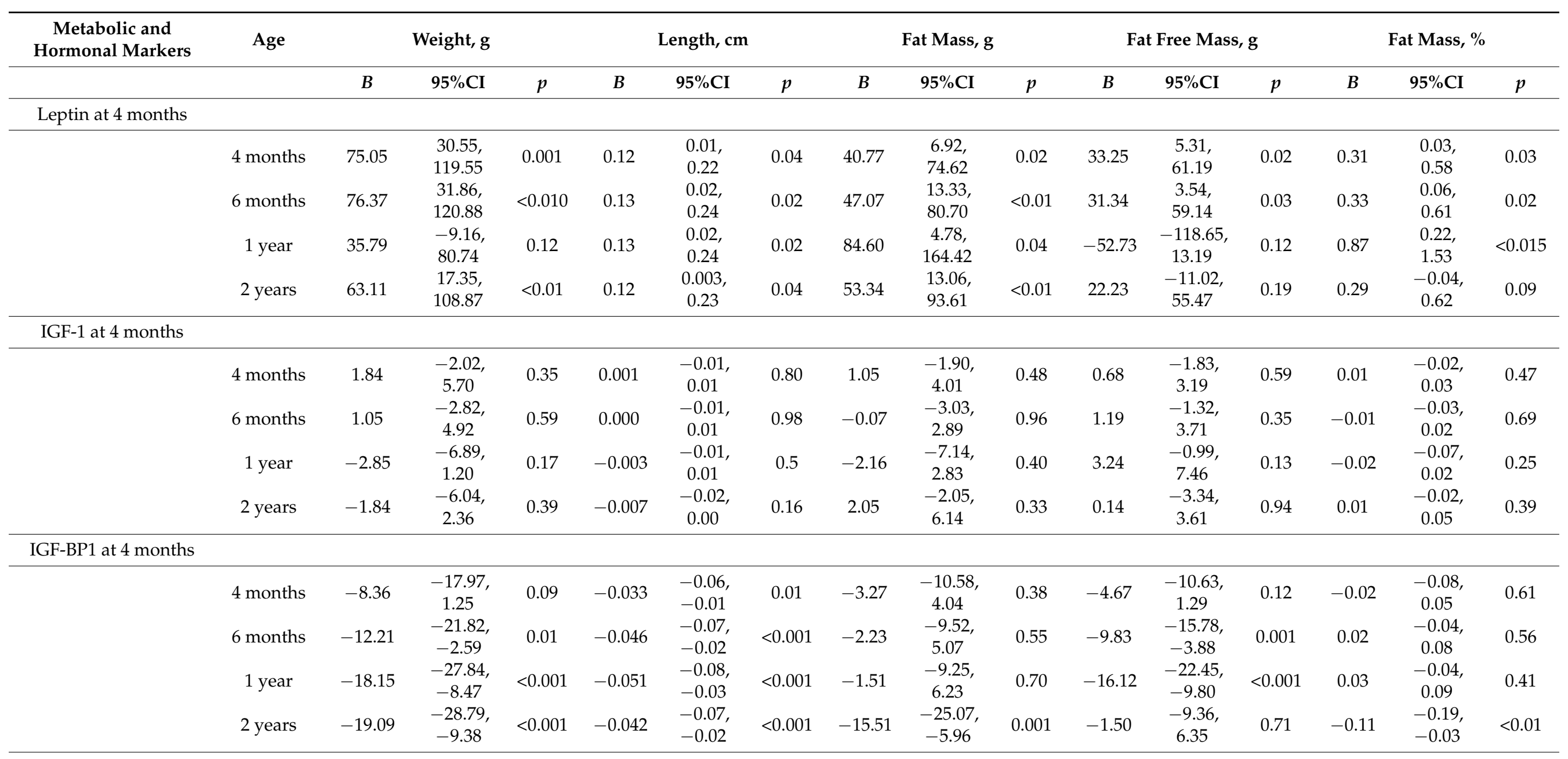


Table 5. Cont.

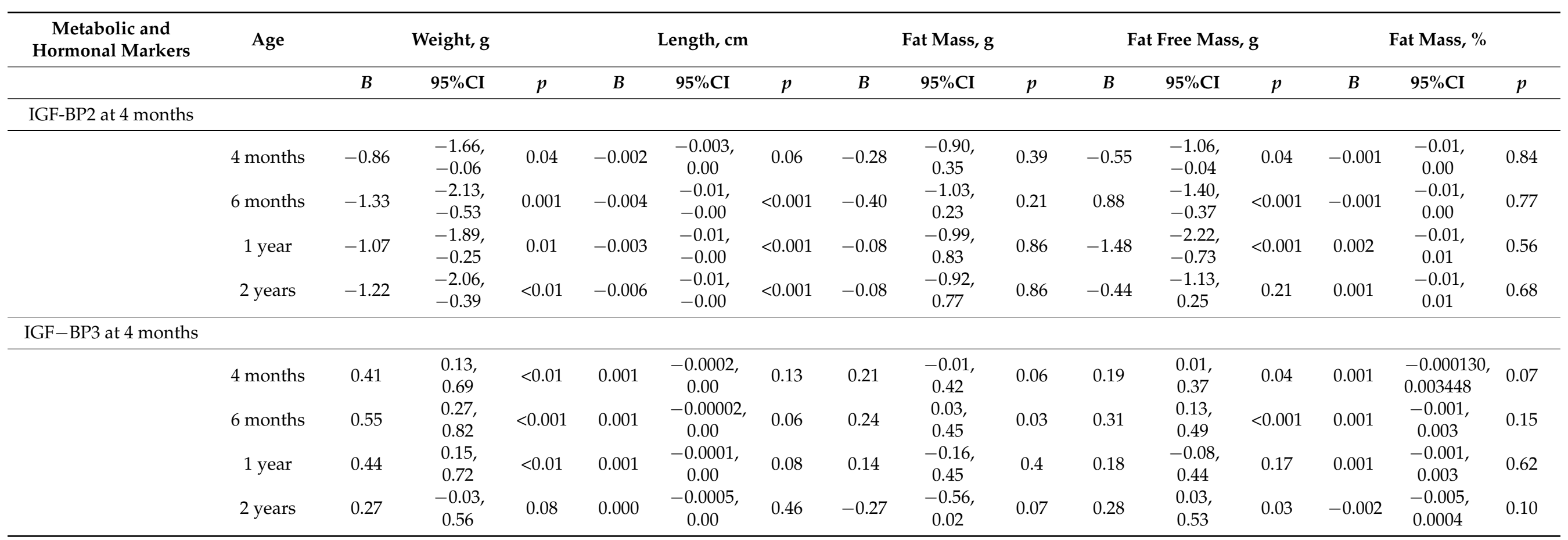

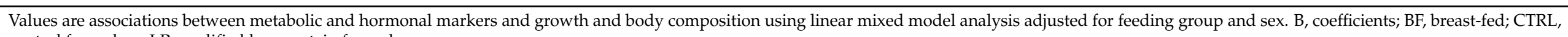
control formula; mLP, modified low-protein formula. 


\subsection{Associations between Early Metabolic and Hormonal Markers and Long-Term Anthropometric Parameters}

Glucose at 4 months was positively associated with fat free mass at 2 years. In contrast, insulin and HOMA were negatively associated with fat free mass at that age. No other associations were found between these markers and long-term growth.

Leptin at 4 months was positively associated with all anthropometric outcomes at all ages except for weight and fat free mass at 1 year as well as fat free mass and fat mass percentage at 2 years. IGF- 1 at 4 months was not associated with anthropometric outcomes until the age of 2 years. IGF-BP1 and IGF-BP2 at 4 months were negatively associated with weight and length from 6 months up to 2 years. Furthermore, IGF-BP1 was negatively associated with fat free mass at 6 months and 1 year. At the age of 2 years, we found a negative association with fat mass and fat mass percentage. In contrast, IGF-BP2 was positively associated with fat free mass at 6 months. However, this association was negative at the age of 1 year. IGF-BP3 at 4 months was positively associated with weight, fat mass, and fat free mass at the age of 6 months. IGF-BP3 was still positively associated with weight at the age of 1 year. Again a positive association was found with fat free mass at 2 years.

Excluding the body composition results obtained at the age of 1 year with $\mathrm{D}_{2} \mathrm{O}$, there was no change in the results (level of significance) except for the association between insulin and fat mass percentage (Supplementary Table S1). In contrast to the complete analysis $(p=0.06$, Table 5), we found an association between insulin and fat mass percentage at the age of 2 years in the analysis with exclusive ADP body composition measurements $(p=0.04$, Supplementary Table S1).

\section{Discussion}

In contrast to our hypothesis, we found similar levels of metabolic and hormonal markers along with similar growth [23] in infants fed mLP formula and infants fed CTRL formula at the age of 4 months despite the lower protein intake in the mLP infants.

Previously, two double-blind randomized controlled trials investigated the effect of protein content in infant formula on metabolic hormones in healthy infants. The CHOP study investigated the long-term effects of total protein intakes of a higher protein infant formula (2.9 g protein/100 kcal for 0-4 months and 4.4 for 4-12 months) compared with formulas with lower protein amounts (1.77 and $2.2 \mathrm{~g}$ protein/100 kcal, respectively) [11]. The EPOCH study examined the effect of a different protein intake on IGF-1 concentration. Infants consumed a high-protein formula $(2.7 \mathrm{~g}$ protein $/ 100 \mathrm{kcal})$ or a low-protein formula $(1.8 \mathrm{~g}$ protein $/ 100 \mathrm{kcal})$ until the age of 1 year.

In line with these studies, we found that formula-fed infants were more insulinresistant as seen by the levels of insulin, IGF-BP1/IGF-BP2, and HOMA-IR than breastfed infants. However, conflicting results are found upon comparing markers of insulin resistance in formula-fed infants with different protein intakes [10,11]. These different findings might be caused by the difference in total protein intake between the interventionand the control group included in these studies. In these studies, the formulas used differed by 1.1 (age $0-4$ months) and 2.2 g protein/100 kcal (age $4-12$ months) (CHOP), as well as $0.9 \mathrm{~g}$ protein $/ 100 \mathrm{kcal}(\mathrm{EPOCH})$.

Although short-term associations between insulin and fat mass percentage are described at the age of 3 months [9], we did not find associations between insulin, glucose, and HOMA-IR at 4 months and body composition during the first year of life; these associations were seen at 2 years of age. This may suggest that the reduction in insulin sensitivity early in life affects body composition at a later age rather than the opposite. There is conflicting evidence comparing IGF-1 levels in formula-fed infants with different protein intakes $[10,11]$. In contrast to the studies described above, we found no significant differences in IGF-1 level between formula-fed and breast-fed infants. Furthermore, no associations between IGF- 1 at the age of 4 months and anthropometric parameters and body composition were found until the age of 2 years, which is in contrast to other studies 
in newborn infants $[11,29,30]$. In contrast to our findings, both the CHOP and $\mathrm{EPOCH}$ found significantly higher IGF-BP2 levels in their low protein group compared to their high protein group $[10,11]$. Furthermore, their breast-fed groups showed higher IGF-BP2 levels compared to both formula groups. In line with our results, IGF-BP3 was not different between the formula groups. Both studies found significantly lower levels of IGF-BP3 in their breast-fed group than in their formula-fed groups. IGF-BP1 was not determined in either study. These different findings highlight the complexity of the effect of IGF-1 on growth and body composition and the role of protein intake in infants: Both protein quantity and quality may be relevant to consider in this respect.

We found that leptin levels were not affected by protein intake. Although leptin levels at four months of age did not differ across the three feeding groups, they were positively associated with anthropometric parameters and body composition including fat mass, fat free mass, and fat mass percentage through the age of 2 years. There is conflicting evidence regarding leptin levels of formula-fed and breast-fed infants [31,32]. Our findings are in contrast with a study in healthy term-born infants $(n=197)$ investigating the fasting serum levels of appetite-regulating hormones including leptin. They found that formula-fed infants had significantly higher leptin levels at 3 months of age compared to breast-fed infants. In line with our results, these values correlated positively with fat mass percentage at 3 months and 6 months [9]. Our study has several strengths and limitations. We used a unique customized blend of essential amino acids in our mLP formula. Its composition is based on outcomes of clinical trials conducted in healthy term-born formula-fed infants. Furthermore, at the age of 4 months, no complementary feeding was introduced, so our findings could be attributed solely to a difference in protein intake by infant formula used at that age. An important limitation was that the infants were about one month of age at enrollment, and more than $50 \%$ of the infants in the formula groups received breast-milk for some period, with unknown effect on the outcomes studied. The low proportion of participants whose blood was sampled, was partly caused by unsuccessful blood draws. For practical reasons related to the type of measurement only limited numbers of participants had a successful body composition measurement at the ages of 1 and 2 years.

In conclusion, at the age of 4 months, infants fed a mLP formula did not differ from those fed a CTRL formula in their metabolic profile despite a $20 \%$-reduction in protein intake, which emphasizes the safety of this low-protein infant formula. We found that formula-fed infants had lower insulin sensitivity compared to breast-fed infants. Furthermore, long-lasting associations were found between all markers and growth and body composition except for IGF-1. Our results showed that the differences found in growth and body composition between formula-fed and breast-fed infants [23] cannot be explained by differences in IGF-1 level at four months of age, but do suggest that the binding proteins and insulin sensitivity play an important role in growth and body composition trajectories.

Supplementary Materials: The following are available online at https:/ /www.mdpi.com/article/10 $.3390 /$ nu13041159/s1, Table S1. Metabolic and hormonal markers in relation to growth and body composition (measured with ADP only) until the age of 2 years.

Author Contributions: S.M.P.K., J.B.v.G., and B.V.K. designed the research; S.M.P.K. and M.F. implemented and conducted the research; S.M.P.K. and J.W.R.T. performed the statistical analyses; S.M.P.K., M.J.J.F., and J.B.v.G. interpreted the data and wrote the paper; D.v.H. conducted laboratory analyses; E.M.v.d.B., M.A.-B., and B.J.M.v.d.H. reviewed the manuscript; all authors critically revised the manuscript; S.M.P.K. holds the primary responsibility for the final content. All authors have read and agreed to the published version of the manuscript.

Funding: The research leading to these results has received funding from the European Union's Seventh Framework Programme (FP7/2007-2013), project Early Nutrition under grant agreement no. 289346 and the European Research Council Advanced Grant META-GROWTH ERC-2012AdG-no.322605. The work of BK is supported by the Else Kröner-Seniorprofessorship of Paediatrics cofunded by the Else Kröner-Fresenius-Foundation, Bad Homburg, Germany and the LMU University 
Hospitals. The research was financially supported by Danone Nutricia Research. The study formulas were designed, produced and supplied by Danone Nutricia Research. Danone Nutricia Research had no role in the execution of the study, or in the statistical analyses of the results.

Institutional Review Board Statement: The trial was approved by the Institutional Review Boards of VU University Medical Center Amsterdam (2014.190, 11 September 2014) and of the Medical Faculty, LMU Munich (284-14, 13 November 2014). The study was conducted according to ICH-GCP principles and in compliance with the principles of the Declaration of Helsinki. An independent data safety monitoring board monitored trial safety.

Informed Consent Statement: Written informed consent was obtained from all participants' parents or guardians.

Acknowledgments: We thank the children and parents who participated in this clinical trial. We also thank Charlotte Ruys and Marita de Waard for performing blood draws.

Conflicts of Interest: M.A.-B. and B.J.M.v.d.H. are employees of Danone Nutricia Research. E.M.v.d.B. was an employee of Danone Nutricia Research when the study was conducted. They had no role in the execution of the study or in the statistical analyses of the results.

Clinical Trial Registry: This trial was registered in the Dutch Trial Register (Study ID number NTR4829, trial number NL4677). https:/ / www.trialregister.nl/trial/4677.

\section{References}

1. Weber, M.; Grote, V.; Closa-Monasterolo, R.; Escribano, J.; Langhendries, J.P.; Dain, E.; Giovannini, M.; Verduci, E.; Gruszfeld, D.; Socha, P.; et al. Lower protein content in infant formula reduces BMI and obesity risk at school age: Follow-up of a randomized trial. Am. J. Clin. Nutr. 2014, 99, 1041-1051. [CrossRef] [PubMed]

2. Gruszfeld, D.; Weber, M.; Gradowska, K.; Socha, P.; Grote, V.; Xhonneux, A.; Dain, E.; Verduci, E.; Riva, E.; Closa-Monasterolo, R.; et al. Association of early protein intake and pre-peritoneal fat at five years of age: Follow-up of a randomized clinical trial. Nutr. Metab. Cardiovasc. Dis. 2016, 26, 824-832. [CrossRef]

3. Rzehak, P.; Grote, V.; Lattka, E.; Weber, M.; Gruszfeld, D.; Socha, P.; Closa-Monasterolo, R.; Escribano, J.; Giovannini, M.; Verduci, E.; et al. Associations of IGF-1 gene variants and milk protein intake with IGF-I concentrations in infants at age 6 months-Results from a randomized clinical trial. Growth Horm. IGF Res. 2013, 23, 149-158. [CrossRef] [PubMed]

4. Koletzko, B.; von Kries, R.; Closa, R.; Escribano, J.; Scaglioni, S.; Giovannini, M.; Beyer, J.; Demmelmair, H.; Gruszfeld, D.; Dobrzanska, A.; et al. Lower protein in infant formula is associated with lower weight up to age $2 \mathrm{y}$ : A randomized clinical trial. Am. J. Clin. Nutr. 2009, 89, 1836-1845. [PubMed]

5. Lind, M.V.; Larnkjaer, A.; Molgaard, C.; Michaelsen, K.F. Dietary protein intake and quality in early life: Impact on growth and obesity. Curr. Opin. Clin. Nutr. Metab. Care 2017, 20, 71-76. [CrossRef]

6. Ketelslegers, J.M.; Maiter, D.; Maes, M.; Underwood, L.E.; Thissen, J.P. Nutritional regulation of the growth hormone and insulin-like growth factor-binding proteins. Horm. Res. 1996, 45, 252-257. [CrossRef]

7. Karlberg, J.; Jalil, F.; Lam, B.; Low, L.; Yeung, C.Y. Linear growth retardation in relation to the three phases of growth. Eur. J. Clin. Nutr. 1994, 48 (Suppl. 1), S25-S43, discussion S43-S44. [PubMed]

8. Hoppe, C.; Udam, T.R.; Lauritzen, L.; Molgaard, C.; Juul, A.; Michaelsen, K.F. Animal protein intake, serum insulin-like growth factor I, and growth in healthy 2.5-y-old Danish children. Am. J. Clin. Nutr. 2004, 80, 447-452. [CrossRef]

9. Breij, L.M.; Mulder, M.T.; van Vark-van der Zee, L.C.; Hokken-Koelega, A.C.S. Appetite-regulating hormones in early life and relationships with type of feeding and body composition in healthy term infants. Eur. J. Nutr. 2017, 56, 1725-1732. [CrossRef] [PubMed]

10. Putet, G.; Labaune, J.M.; Mace, K.; Steenhout, P.; Grathwohl, D.; Raverot, V.; Morel, Y.; Picaud, J.C. Effect of dietary protein on plasma insulin-like growth factor-1, growth, and body composition in healthy term infants: A randomised, double-blind, controlled trial (Early Protein and Obesity in Childhood (EPOCH) study). Br. J. Nutr. 2016, 115, 271-284. [CrossRef] [PubMed]

11. Socha, P.; Grote, V.; Gruszfeld, D.; Janas, R.; Demmelmair, H.; Closa-Monasterolo, R.; Subias, J.E.; Scaglioni, S.; Verduci, E.; Dain, E.; et al. Milk protein intake, the metabolic-endocrine response, and growth in infancy: Data from a randomized clinical trial. Am. J. Clin. Nutr. 2011, 94 (Suppl. 6), 1776S-1784S.

12. Madsen, A.L.; Larnkjaer, A.; Molgaard, C.; Michaelsen, K.F. IGF-I and IGFBP-3 in healthy 9 month old infants from the SKOT cohort: Breastfeeding, diet, and later obesity. Growth Horm. IGF Res. 2011, 21, 199-204. [CrossRef]

13. Chellakooty, M.; Juul, A.; Boisen, K.A.; Damgaard, I.N.; Kai, C.M.; Schmidt, I.M.; Petersen, J.H.; Skakkebaek, N.E.; Main, K.M. A prospective study of serum insulin-like growth factor I (IGF-I) and IGF-binding protein-3 in 942 healthy infants: Associations with birth weight, gender, growth velocity, and breastfeeding. J. Clin. Endocrinol. Metab. 2006, 91, 820-826. [CrossRef] [PubMed]

14. Savino, F.; Fissore, M.F.; Grassino, E.C.; Nanni, G.E.; Oggero, R.; Silvestro, L. Ghrelin, leptin and IGF-I levels in breast-fed and formula-fed infants in the first years of life. Acta Paediatr. 2005, 94, 531-537. [CrossRef] [PubMed] 
15. Bang, P.; Nygren, J.; Carlsson-Skwirut, C.; Thorell, A.; Ljungqvist, O. Postoperative induction of insulin-like growth factor binding protein-3 proteolytic activity: Relation to insulin and insulin sensitivity. J. Clin. Endocrinol. Metab. 1998, 83, 2509-2515. [CrossRef]

16. Firth, S.M.; Baxter, R.C. Cellular actions of the insulin-like growth factor binding proteins. Endocr. Rev. 2002, 23, 824-854. [CrossRef]

17. Duan, C.; Xu, Q. Roles of insulin-like growth factor (IGF) binding proteins in regulating IGF actions. Gen. Comp. Endocrinol. 2005, 142, 44-52. [CrossRef]

18. Haywood, N.J.; Slater, T.A.; Matthews, C.J.; Wheatcroft, S.B. The insulin like growth factor and binding protein family: Novel therapeutic targets in obesity \& diabetes. Mol. Metab. 2019, 19, 86-96.

19. Yau, S.W.; Harcourt, B.E.; Kao, K.T.; Alexander, E.J.; Russo, V.C.; Werther, G.A.; Sabin, M.A. Serum IGFBP-2 levels are associated with reduced insulin sensitivity in obese children. Clin. Obes. 2018, 8, 184-190. [CrossRef]

20. Ko, J.M.; Park, H.K.; Yang, S.; Kim, E.Y.; Chung, S.C.; Hwang, I.T. Association between insulin-like growth factor binding protein-2 levels and cardiovascular risk factors in Korean children. Endocr. J. 2012, 59, 335-343. [CrossRef]

21. Miralles, O.; Sanchez, J.; Palou, A.; Pico, C. A physiological role of breast milk leptin in body weight control in developing infants Obesity 2006, 14, 1371-1377. [CrossRef]

22. Lonnerdal, B.; Havel, P.J. Serum leptin concentrations in infants: Effects of diet, sex, and adiposity. Am. J. Clin. Nutr. 2000, 72, 484-489. [CrossRef]

23. Kouwenhoven, S.M.P.; Antl, N.; Finken, M.J.J.; Twisk, J.W.R.; van der Beek, E.M.; Abrahamse-Berkeveld, M.; van de Heijning, B.J.M.; Schierbeek, H.; Holdt, L.M.; van Goudoever, J.B.; et al. A modified low-protein infant formula supports adequate growth in healthy, term infants: A randomized, double-blind, equivalence trial. Am. J. Clin. Nutr. 2019, 111, 962-974. [CrossRef] [PubMed]

24. Schierbeek, H.; van den Akker, C.H.; Fay, L.B.; van Goudoever, J.B. High-precision mass spectrometric analysis using stable isotopes in studies of children. Mass Spectrom. Rev. 2012, 31, 312-330. [CrossRef]

25. Schierbeek, H.; Rieken, R.; Dorst, K.Y.; Penning, C.; van Goudoever, J.B. Validation of deuterium and oxygen18 in urine and saliva samples from children using on-line continuous-flow isotope ratio mass spectrometry. Rapid Commun. Mass Spectrom. 2009, 23, 3549-3554. [CrossRef]

26. Kouwenhoven, S.M.; de Waard, M. Early-life Nutrition and Stable Isotope Techniques. In Mass Spectrometry and Stable Isotopes in Nutritional and Pediatric Research; Schierbeek, H., Ed.; John Wiley \& Sons: Hoboken, NJ, USA, 2017.

27. Butte, N.F.; Hopkinson, J.M.; Wong, W.W.; Smith, E.O.; Ellis, K.J. Body composition during the first 2 years of life: An updated reference. Pediatr. Res. 2000, 47, 578-585. [CrossRef]

28. Matthews, D.R.; Hosker, J.P.; Rudenski, A.S.; Naylor, B.A.; Treacher, D.F.; Turner, R.C. Homeostasis model assessment: Insulin resistance and beta-cell function from fasting plasma glucose and insulin concentrations in man. Diabetologia 1985, 28, 412-419. [CrossRef]

29. Low, L.C.; Tam, S.Y.; Kwan, E.Y.; Tsang, A.M.; Karlberg, J. Onset of significant GH dependence of serum IGF-I and IGF-binding protein 3 concentrations in early life. Pediatr. Res. 2001, 50, 737-742. [CrossRef]

30. Closa-Monasterolo, R.; Ferre, N.; Luque, V.; Zaragoza-Jordana, M.; Grote, V.; Weber, M.; Koletzko, B.; Socha, P.; Gruszfeld, D.; Janas, R.; et al. Sex differences in the endocrine system in response to protein intake early in life. Am. J. Clin. Nutr. 2011, 94 (Suppl. 6), 1920S-1927S.

31. Petridou, E.; Mantzoros, C.S.; Belechri, M.; Skalkidou, A.; Dessypris, N.; Papathoma, E.; Salvanos, H.; Lee, J.H.; Kedikoglou, S.; Chrousos, G.; et al. Neonatal leptin levels are strongly associated with female gender, birth length, IGF-I levels and formula feeding. Clin. Endocrinol. 2005, 62, 366-371. [CrossRef]

32. Savino, F.; Nanni, G.E.; Maccario, S.; Costamagna, M.; Oggero, R.; Silvestro, L. Breast-fed infants have higher leptin values than formula-fed infants in the first four months of life. J. Pediatr. Endocrinol. Metab. 2004, 17, 1527-1532. [CrossRef] [PubMed] 